\title{
Can Orthodox Biblical Theology be Autonomous?
}

\author{
The Case of the Bible from 1914
}

\author{
Constantin OAncea*
}

\begin{abstract}
The current trend among Orthodox theologians is to identify a fitting profile for biblical theology. The ecclesial and pneumatological dimension of biblical interpretation and the recovery of the patristic spirit of exegesis are the main principles invoked. Should Orthodox biblical theology develop autonomously, ignoring western biblical theology? The case of the Bible from 1914 analysed in this study shows that Orthodox biblical theology should develop taking into account heterodox biblical theology and making reference to its results.
\end{abstract}

Keywords: Orthodox biblical theology, Bible from 1914, Blaj Bible, Bucharest Bible

That Orthodox theology experienced a new approach in the $20^{\text {th }}$ century is no longer a novelty to anyone. The same holds true for the finding that influences for such an adjustment have come from the outside, as a result of reform movements in Roman Catholic theology. Orthodox biblical theology confronted the influences for a "new hermeneutic" positively, namely as concern for its Orthodox character in relation to Western biblical science. In an attempt to define their own identity, Orthodox theologians have made contributions that are worthy of consideration and outlined some specific features of the Orthodox interpretation of the Scripture. Of these, the ecclesial and pneumatological dimension of biblical reading and the recovery of the patristic spirit of exegesis seem to be the most important ${ }^{1}$.

\footnotetext{
* Revd. Constantin Oancea, PhD, Associated Professor at the Faculty of Orthodox Theology, "Lucian Blaga" University of Sibiu, Romania. Adress: Mitropoliei 20, 550179, Sibiu; e-mail: constantin.oancea@gmx.de.

1 For more details on involvements for Orthodox biblical hermeneutics, see: Elias Oikonomos, Bibel und Bibelwissenschaft in der orthodoxen Kirche, Stuttgart 1976; idem, The Power of the Word in the Worshiping Church, Crestwood, 1986; idem, Scripture in Tradition: The Bible and Its Interpretation in the Orthodox Church, Crestwood, 2001; idem, "Orthodox Principles of Biblical Interpretation", in: SVTQ 40 (1-2/1996), p. 77-93; Paul Evdochimov, "Principes de l'hermeneutique orthodoxe", in: Contacts 136 (1986), p. 289-306; 137 (1987), p. 61 67; 138 (1987), p. 127-135; 141 (1988), p. 69-72; 145 (1989), p. 56-64; Mircea Basarab, Interpretarea Sfintei Scripturi în Biserica Ortodoxă, Cluj 2005; Stelian Tofană, "Cuvântul lui Dumnezeu ca Euharistie: înţelegerea şi interpretarea Bibliei în lumina experienţei euharistice liturgice, din perspectiva ortodoxă", in: Studia Universitatis Babes-Bolyai, Theologia orthodoxa 1-2/1998, p. 109-123; Veselin Kesich, "The Orthodox Church and Biblical Interpretation”,
} 
In what follows, I do not intend to contribute to the discussion on the exegetical method (or methods). Another issue seems to me equally important as hermeneutics, namely the extent to which the future of biblical science in Orthodox theology (Romanian, though not exclusively) should be marked only by the search for its precise character. More specifically - could one practice Orthodox biblical theology while ignoring the results of heterodox biblical theology, as if they did not exist, or merely by engaging in polemics with them?

I believe the example of the past can offer some guidance in the attempt to find an answer to these questions. I will take as a case study a work appreciated by Romanian Orthodox theology - the Synodal Bible (1914) - and seek to identify its relation to heterodox theology.

\section{The Bible from 1914 today}

The fact that I chose this edition of the Holy Bible as a starting point for discussion is not accidental. In 2014 we celebrate one hundred years since the publication of the Bible from 1914 (B1914). Prior to the edition redacted and annotated by Metropolitan Bartolomeu Anania (2001), this was the last Bible printed by the Holy Synod of the Romanian Orthodox Church which included the text of the Septuagint.

This edition enjoys unrivaled appreciation among Romanian editions of the Holy Scripture in some rigorous circles of contemporary Orthodox $\mathrm{Church}^{2}$. In the last few years a facsimile edition has been made available in Romania, with no indication of the place of printing, which may be associated, perhaps, with the group mentioned above. Several web sites offer the possibility of consulting or downloading it in PDF format. A call has been launched for the digitization of this edition, given the imperfect quality of the image in the online version ${ }^{3}$.

in: St Vladimir's Theological Quarterly 37 (4/1993), p. 343-351; Constantin Coman, Erminia Dubului. Texte fundamentale pentru o ermineutică duhovnicească, Bucureşti 2002; Vasile Mihoc, "The Actuality of Church Fathers' Biblical Exegesis", in: James D.G. Dunn, Ulrich Luz et al. (eds.), Auslegung der Bibel in orthodoxer und westlicher Perspektive: Akten des westöstlichen Neutestamentler/Innen-Symposiums von Neamt vom 4.-11. September 1998 (WUNT 130), Tübingen 2000, p. 6-27; Theodore G. Stylianopoulos, "Perspectives in Orthodox Biblical Interpreation", in: Greek Orthodox Theological Review 47 (1-4/2002), p. 327-338; Paul M. Blowers, "Eastern Orthodox Biblical Interpretation", in: A.J. Hauser / D.F. Watson (eds.), A History of Biblical Interpretation: The Medieval Through the Reformation Period, Grand Rapids, 2009, p. 172-200; Alexander I. Negrov, Biblical Interpretation in the Russian Orthodox Church: A Historical and Hermeneutical Perspective, Tübingen, 2008; Eugen J. Pentiuc, The Old Testament in Eastern Orthodox Tradition, Oxford 2014.

2 See: discussions on the Bible from 1914 at http://www.razbointrucuvant.ro/anunturi/ 2008/12/22/apel-pentru-recuperarea-textului-bibliei-din-1914/, viewed 20.05.2014.

3 Ibidem. 
The initiators of the $B 1914$ digitization project justify their proposal by arguing that the two current editions accepted by the Romanian Orthodox Church fall short in several respects. The most widespread edition - dating from 1936, reprinted in 1968, 1975, 1988, 2008 - would not reproduce the text of the Septuagint, being translated from the Hebrew Bible. The other edition - the Bible of Metropolitan Bartolomeu Anania (2001) -presents a language that is too bold in some places, or is not suitable for liturgical use. Moreover, for the correction of the text, Metropolitan Bartolomeu probably used unorthodox resources, "ecumenical or of another nature", whether editions of the Bible in current languages, or secondary sources ${ }^{4}$.

The argument for recovering the $B 1914$ states that its importance is due in some degree to internal arguments, emerging from its comparison to other Romanian editions of the biblical text. More influential has been the fact that theological or spiritual authorities of the Romanian Orthodox Church - Fr Dumitru Stăniloae, Fr Dumitru Fecioru or, more recently, Fr Rafail Noica preferred this edition of the Bible and not the one published in 1936 (and its subsequent editions) 5 .

Here then we highlight the features of the $B 1914$ which, according to its adherents mentioned above, should be recognized as the best version of the Bible in Romanian:

- It is recommended by authoritative theologians of the Orthodox Romanian Church.

- It was translated from the Septuagint and not from the Hebrew Masoretic Text.

- It did not use unorthodox resources.

This view is also shared by some students at the Faculty of Orthodox Theology, since I have often been asked whether the Bible from 1914 is the best Romanian translation of the Scriptures.

To what extent does this perception actually correspond to reality? The first two considerations - the use of the $B 1914$ by theologians of high authority and the fact that it reproduces the text of the Septuagint - are fair enough. The decision of Father Stăniloae to utilize quotations from the B1914 appears natural for someone who works with patristic texts. The $B 1914$ follows the Septuagint, and patristic authors quote or paraphrase this ancient translation. The inclusion of biblical quotes from the Church Fathers according to the

\footnotetext{
4 Ibidem.

5 The information seems to come from the introduction to Anania’s Bible („Cuvânt lămuritor asupra Sfintei Scripturi”, in: Biblia sau Sfânta Scriptură. Ediţie jubiliară a Sfântului Sinod, Bucureşti 2001, p. 11).
} 
Bible from 1936 creates difficulties - if not impossibilities in some cases - as the text of this edition is a compilation according to the Septuagint and the Hebrew Bible. The decision made by the translators of the Bible from 1936 to merge two versions of the text may be questionable as a scientific approach. But to disregard all Romanian editions derived from the Bible from 1936 only because they have resorted to the Hebrew Bible might demonstrate ignorance and anti-Semitic prejudices.

\section{The editors of the Bible from 1914}

Is the B1914 the most "Orthodox" edition of the Holy Scriptures in the Romanian Orthodox Church? To answer this question we should first discuss the circumstances of its publication, and look both at the ones who endeavoured to complete it and at the resources they used. Such information is usually given in the preface of a book. As the Bible from 1914 does not have such a preface, information related to its publication can be found only from printed documents of the time ${ }^{6}$. Published in 1914 at Tipografia Cărţilor Bisericeşti (The Printing House for Religious Books) in Bucharest, this edition is also known as the "Synodal Bible", especially because the members of the Holy Synod of that time made every effort to complete it. It seems that the initiative to reprint the Scripture came from outside the Church, namely from the Ministry of Religious Affairs, in 19087. The project was initiated with the participation of all Synodality, grouped into committees, but in 1909 the work was entrusted to a commission made up of a limited number of members. Due to unfortunate accidents and against a difficult political context, which would culminate in the outbreak of World War I, the new edition of the Bible was published only in $1914^{8}$. Therefore, as regards the "translators" of the Bible from 1914, there is no doubt that they were Orthodox.

6 Information may be found especially in articles and notes about the meetings of the Holy Synod, printed in: Biserica Ortodoxă Română review, between 1908 and 1915. For more details see: Emanuel Conţac, "Tradiţia biblică românească. O prezentare succintă din perspectiva principalelor versiuni româneşti ale Sfintei Scripturi”, in: Studii Teologice 2/2011, p. 159-245, here 191-194.

Father G. Marcu hypothesized that the impetus for this came from the future Metropolitan Bishop of Transylvania, Nicolae Bălan who, in a note addressed in 1912 to the Patriarch Conon Arămescu-Donici, argued for a new edition of the Bible in updated Romanian and also for setting up a biblical society and organizing a Romanian symposium on biblical issues. See: Grigore Marcu, "Iniţiativa transilvăneană în tipărirea Bibliei româneşti”, in: Revista Teologică 1-2/1943, p. 98-103. However, the appeal from the Ministry of Religious Affairs had been initiated 4 years before, in 1908. See: E. Conţac, "Tradiţia”, p. 191.

8 Ibidem, p. 192-194. 


\section{The sources used by the editors}

In terms of resources used by members of the Holy Synod, things appear to be different. Documents of the time clearly indicate that the Synodal Bible was not a new translation, but a revision of the biblical text. The New Testament was reproduced in accordance with the edition of 1905 . For the text of the Old Testament, committee members asked for earlier editions of the Bible in Romanian: the Bibles from Bucharest (1688), Blaj (1795), St. Petersburg (1819), Buzău (1854-1956) and Sibiu (1856-1858). Besides these they also looked at editions of the Septuagint, the Vulgate and the Hebrew Bible 9 . Considering that the Bibles from St. Petersburg, Buzău and Sibiu reproduce, with minor modifications, the text of the Blaj Bible, it appears that those working for the publication of the $B 1914$ used two main textual versions of the Bible in Romanian: the one published in Bucharest in $1688(B B)$ and the one published at Blaj in 1795 (BBlaj).

An overview of three verses from different canonical parts of the Old Testament shows that the text of the BBlaj was adopted, almost without any modification, by the editorial team of the B1914:

\begin{tabular}{|c|c|c|c|}
\hline & Biblia București $(B B)$ & Biblia Blaj (BBlaj) & Biblia 1914 (B1914) \\
\hline Gen 1,2 & $\begin{array}{l}\text { Iară pămîntul era ne- } \\
\text { văzut și netocmit. Şi } \\
\text { întunearec zăcea dea- } \\
\text { supra preste cel fără } \\
\text { de fund, și Duhul lui } \\
\text { Dumnezău Să purta } \\
\text { deasupra apei. }\end{array}$ & $\begin{array}{l}\text { Și pământul era nevă- } \\
\text { zut și netocmit, și în- } \\
\text { tunearec era deasupra } \\
\text { adâncului, și Duhul } \\
\text { lui Dumnezeu să purta } \\
\text { pre deasupra apei }\end{array}$ & $\begin{array}{l}\text { Și pământul erà nevă- } \\
\text { zut și netocmit și în- } \\
\text { tunerec erà deasupra } \\
\text { adâncului; și Duhul } \\
\text { lui Dumnezeu se purtà } \\
\text { pre deasupra apei }\end{array}$ \\
\hline Jos 1,7 & $\begin{array}{l}\text { Întăreaște-te dară și te } \\
\text { vitejaște foarte, să pă- } \\
\text { zești și să faci după cum } \\
\text { au poruncit Moisi, slu- } \\
\text { ga Mea, și să nu te abaţi } \\
\text { de la ei în direapta au în } \\
\text { stînga, pentru ca să pri- } \\
\text { cepi întru toate carele } \\
\text { vei face. }\end{array}$ & $\begin{array}{l}\text { Întăreaște-te, dară, și } \\
\text { te îmbărbătează foarte, } \\
\text { ca să păzești și să faci } \\
\text { precum ţ-au poruncit } \\
\text { Moisi, sluga Mea, și să } \\
\text { nu te abaţi de la acealea } \\
\text { de-a dreapta au de-a } \\
\text { stânga, ca să fii înţelept } \\
\text { întru toate ceale ce vei } \\
\text { face. }\end{array}$ & $\begin{array}{l}\text { Întărește-te dar şi te } \\
\text { îmbărbătează foarte, } \\
\text { ca să păzești și să faci } \\
\text { precum ţi-a poruncit } \\
\text { Moisì sluga mea, și să } \\
\text { nu te abaţi de la acelea } \\
\text { deadreapta sau deas- } \\
\text { tânga, ca să fii înţelept } \\
\text { întru toate cele ce vei } \\
\text { face. }\end{array}$ \\
\hline
\end{tabular}

9 Ibidem. 


\begin{tabular}{|l|l|l|l|}
\hline Ps 1,1 & $\begin{array}{l}\text { Fericit omul carele } \\
\text { n-au mersu în sfatul } \\
\text { necuraţilor și în ca- }\end{array}$ & $\begin{array}{l}\text { Fericit bărbatul carele } \\
\text { n-au umblat în sfatul } \\
\text { necredincioșilor și în }\end{array}$ & $\begin{array}{l}\text { Fericit bărbatul, care } \\
\text { n-a umblat în sfatul } \\
\text { necredincioșilor, și în }\end{array}$ \\
$\begin{array}{l}\text { stătut și pre scaunul } \\
\text { ucigașilor n-au șezut. }\end{array}$ & $\begin{array}{l}\text { calea păcătoșilor n-au } \\
\text { stătut și pre scaonul } \\
\text { pierzătorilor n-au șezut. }\end{array}$ & $\begin{array}{l}\text { calea păcătoșilor n-a } \\
\text { stătut, și pre scaunul } \\
\text { pierzătorilor n-a șezut. }\end{array}$ \\
\hline Hos 4,5 & $\begin{array}{l}\text { Și va slăbi zile, va } \\
\text { slăbi și prorocul îm- } \\
\text { preună cu el noaptea } \\
\text { și asămănat-am pre } \\
\text { maica ta. }\end{array}$ & $\begin{array}{l}\text { Și va slăbi din zi în zi } \\
\text { și va slăbi prorocul cu } \\
\text { tine; nopţii am asămă- } \\
\text { nat pre mumă-ta. }\end{array}$ & $\begin{array}{l}\text { Și va slăbì din zi în zi, } \\
\text { și va slăbì prorocul cu } \\
\text { tine, nopţei am asemă- } \\
\text { nat pre muma ta. }\end{array}$ \\
\hline
\end{tabular}

Even someone who does not speak Romanian will notice that the differences between the B1914 and the BBlaj are minor, most cases involving the replacement of obsolete words and expressions.

Moreover, some mistakes in the BBlaj-corrected in the errata - were reproduced as such by the editions of St. Petersburg, Buzău and Sibiu ${ }^{10}$. Two of them are found in the B1914:

\begin{tabular}{|c|c|c|c|c|}
\hline & $B B$ & BBlaj & B1914 & LXX Rahlfs \\
\hline Ios 17,9 & Iair & Air & Air & Iariēl \\
\hline Mal 1,3 & $\begin{array}{l}\text { am rînduit hotarăle lui } \\
\text { "I appointed his } \\
\text { territory" }\end{array}$ & $\begin{array}{l}\text { am hotarăle lui }{ }^{2} \\
\text { "I his territory" } \\
\text { (The verb is } \\
\text { omitted) }\end{array}$ & $\begin{array}{l}\text { am } \\
\text { hotarele lui }\end{array}$ & $\begin{array}{l}\text { etaxa ta oria } \\
\text { autou }\end{array}$ \\
\hline
\end{tabular}

Without going into comparative details, we mention two more situations of this kind.

a) In 3 Kings 17, 22, the $B 1914$ prefers the form "the child resurrected" instead of "the child cried out (aneboèsen)", as it appears in the $B B$ and the BBlaj. But the version "the child resurrected" was indicated in the explanatory notes in the BBlaj, referencing its liturgical source ${ }^{11}$.

b) The B1914 adopted, in accordance with the BBlaj, the translation Gr. enkruphias:

10 According to Ioan Chindriş, "Secolele Bibliei de la Blaj", in: Biblia de la Blaj 1975. Ediţie jubiliară, Roma 2000, p. 2406-2407, these are present in Deut 2,37, Jos 17,7.9 and Mal 1,3. It is highly probable that the Sibiu Bible has taken these mistakes from the text of the St. Petersburg Bible, as evidenced from the comparison of mistakes common to both editions, but which do not appear in the Blaj Bible: Gen 36,24 and Isa 27,12. See: E. Conţac, “Tradiţia”, p. 190.

11 The paroimia (Old Testament reading) on the Holy and Great Saturday. 


\begin{tabular}{|l|l|l|l|}
\hline Enkruphias & BB & BBlaj & B1914 \\
\hline Fac 18,6 & $\begin{array}{l}\text { Azime } \\
\text { (Unleavened bread) }\end{array}$ & Azime & Azime \\
\hline Ieş 12,39 & Azime & $\begin{array}{l}\text { Turte } \\
\text { (Cake) }\end{array}$ & Turte \\
\hline Num 11,8 & Turte & $\begin{array}{l}\text { Pogăci } \\
\text { (Dialect word for cake) }\end{array}$ & Azimi \\
\hline 3Regi $17,12.13$ & Turtă & Azimă & Azimă \\
\hline 3Regi 19,6 & Turtă & Azimă & Azimă \\
\hline Os 7,8 & Azimă & Azimă & Azimă \\
\hline Iez 4,12 & Turtă & Turtă & Turtă \\
\hline
\end{tabular}

Only in one of the seven occurrences (Num 11,8) there is a difference between the B1914 and the BBlaj.

In conclusion, the main resource of the $B 1914$ was not from the Orthodox realm, but from the BBlaj, printed in 1795 by the Greek-Catholic Church of Transylvania.

\section{The adoption of the Blaj Bible}

However, Orthodox hierarchs decided to adopt this heterodox translation on four occasions. The $B 1914$ was the last instance. Publishers of the St. Petersburg Bible (1819) asked for the opinion of the Metropolitan of Bessarabia, Gavriil Bănulescu Bodoni, who recommended the BBlaj as first source for the text ${ }^{12}$. Bishop Filotei of Buzău, native of Făgăraş County in Transylvania, also knew to appreciate the value of the BBlaj, which was used both by Greek-Catholics and Orthodoxes in Transylvania. In the foreword, Bishop Filotei admitted that he had chosen to reprint the BBlaj, as it was the best and clearest translated Romanian edition of the Holy Scripture. The Bible printed in Buzău even included the introductory study on the Holy Scriptures from the Blaj edition. On another occasion, Filotei argued for his choice to reprint the text of Blaj by saying that the Metropolitan of Moldavia, Veniamin Costachi, had also reprinted that text ${ }^{13}$. In Sibiu Metropolitan Andrei Şaguna reprinted the same Bible, even if he used the St. Petersburg Bible as primary source. The hierarch of Sibiu does not mention the BBlaj in his preface, but it is highly improbable that he did not know what text had been used as source for the St. Petersburg Bible. In all these cases, when hierarchs of the Orthodox

12 Nicolae I. Nicolaescu, "Scurt istoric al traducerii Sfintei Scripturi. Principalele ediţii ale Bibliei în Biserica Ortodoxă Română”, in: Studii Teologice 7-8/1974, p. 489-521, here 508-509. 13 See: Andrei Şaguna, Corespondenţa, vol. I/1, edited by Nicolae Bocşan, Ioan-Vasile Leb et al., Cluj-Napoca 2005, p. 235-236. 
Church of Moldavia, Wallachia and Transylvania decided to reissue the BBlaj, they did not consider the religious origin of the source text as most important, but rather its value.

\section{The heterodox sources of the Blaj Bible}

The value of the Blaj Bible is not only due to the erudition and accuracy of its editor, Samuil Micu, but also to the resources he used. Among the sources used by the theologian from Blaj one can identify the first full translation of the Bible in the Romanian Orthodox Church: the Bucharest Bible (1688). The Psalms were reproduced by Samuil Micu in accordance with the Blaj Psalter (1764), that itself reproduced the text of the Buzău Psalter $(1703)^{14}$.

But most of the works used by Samuil Micu were neither Orthodox nor Greek-Catholic. The scholar from Blaj had completed his studies at the Pazmaneum College in Vienna (1766-1772). He made the decision to translate the Bible in 1783, when he was prefect of studies at the College of St. Barbara in the same city $(1777-1783)^{15}$. Vienna was home to one of the oldest universities in Europe (from 1365), so that in libraries and bookstores there, Samuil Micu could have found the most important critical editions of the biblical text. Although Samuil Micu did not state explicitly which edition he had used, researchers reported several probable or possible sources ${ }^{16}$. Among these:

- The Complutensian Polyglot Bible, published in Alcala (Spain) in 1514-1517, is even mentioned in the footnotes of Samuil Micu ${ }^{17}$. It included, besides the first printed edition of the Septuagint, the text of the Hebrew Bible, the Targum Onkelos, the Vulgate and the Greek New Testament as well. Humanist theologians and philologists participated in its creation, while its publication and the printing costs of the 6 volumes were associated with Cardinal Francisco Ximenez de Cisneros, Archbishop of Toledo. Samuil Micu probably had no direct access to the Complutensian Polyglot Bible, but to one of the polyglot editions that followed it (Antwerpen, 1569-1572; Paris, 1645; London, 1657). That might explain the references to some versions of the Old Testament (Syriac, the Samaritan Pentateuch, Arabic and Persian

14 Eugen Pavel, "Un monument de limbă literară: Biblia lui Samuil Micu”, in: Biblia de la Blaj 1975. Ediţie jubiliară, Roma 2000, p. 2425.

15 E. Pavel, "Un monument", p. 2421.

16 See: Ibidem, p. 2422-2423; I. Chindriş, "Secolele”, p. 2393-2396.

17 Biblia de la Blaj, p. 252; 414. 
versions), found in the notes to the $B B l a j^{18}$, which are not present in the Complutensian ${ }^{19}$.

- For the text of the Septuagint, Samuil Micu allegedly used the edition of the humanist Lambert Bos, published in Franeker (1709), perhaps because a copy of this paper existed in the library of the monks from Blaj $^{20}$. L. Bos had critically reviewed the Sixtine text (Rome 1587), which was based on Codex Vaticanus, indicating in the critical apparatus variants of previous manuscripts and editions ${ }^{21}$. However, the BBlaj deviates in several places from the text edited by L. Bos and is closer to the $B B$, which was based on the Aldine text (Venice, 1518), and produced in accordance with the Frankfurt edition (1597). Micu had probably read Bos's edition and used its critical apparatus, but did not follow the text of the Septuagint proposed by the Dutch scholar. It is possible that Micu might have opted for an older text in deference to the Romanian biblical tradition initiated by the Bucharest Bible ${ }^{22}$.

- In addition to the Old Testament books printed in the $B B$, the BBlaj also includes the Prayer of Manasseh ${ }^{23}$. This writing, considered apocryphal or pseudepigraphal in Judaism, Catholicism and Protestantism, is attested in some ancient writings, probably because of its use in liturgy $^{24}$. From the Thirteenth century on, the Latin version is found in manuscripts of the Vulgate. Most printed editions of the Septuagint prior to the $20^{\text {th }}$ century do not include the Prayer of Manasseh. We do not know exactly what source Samuil Micu actually used ${ }^{25}$. The Vulgate translation of Petru Pavel Aron (1760-1761) was available in manuscript to Micu, but this version of the Prayer differs in places from that of the BBlaj. The text of the Prayer was present in the Complutensian

18 Biblia de la Blaj, p. 36; 110.

19 Arabic and Persian variants appear only in the Polyglot from London.

20 I. Chindriş, "Secolele", p. 2347; E. Pavel, "Un monument", p. 2422.

21 See: Richard R. Ottley, A Handbook to the Septuagint, New-York 1920, p. 66.

22 See: Chindriş's considerations in this respect ("Secolele", p. 2394-2396).

23 Biblia de la Blaj, p. 893-894.

24 Apostolic Constitutions, the Syriac version of Didascalia, Codex Alexandrinus, Codex Turicensis. For more details see James H. Charlesworth, The Old Testament Pseudoepigrapha, vol. 2, Garden City, NY 1985, p. 625-637. Thomas Knittel, Gebet Manasses, at http://www. bibelwissenschaft.de/stichwort/19038/, viewed 27.05.2014.

25 E. Pavel supposes that Micu translated the text from Latin ("Un monument", p. 24272428). 
Polyglot (in Latin), in the Polyglot from London (in Greek and Latin), in some reprints of the Sixtine Septuagint ${ }^{26}$, in the Sixto-Clementine Vulgate Appendix (1592) and in some Bibles from $16^{\text {th }}-17^{\text {th }}$ centuries. The identification of the source used by Micu cannot be investigated within the limits of this article and deserves a special study. What is important, however, is that the BBlaj initiated a textual tradition including the Prayer of Manasseh, since all editions of the Bible in the Romanian Orthodox Church print this book among the anaginoskomena books of the Old Testament ${ }^{27}$. Keeping the Prayer of Manasseh in the Bible editions of the Romanian Orthodox Church was surely influenced by its liturgical use, while 4Maccabees - an apocryphal that also appeared in the $B B^{28}$ and $B B l a j^{29}$ had not been printed in any subsequent Romanian edition. It is worth mentioning here that there is no uniform practice in Orthodoxy as regards the printing of the Prayer of Manasseh in the Bible, or its location among the Old Testament books. ${ }^{30}$

The publication of most works mentioned above, as possible resources used by Samuil Micu, was initiated and sponsored by the ecclesiastical Roman-Catholic and Protestant authorities. In terms of their scientific quality, these works were the result of labours of humanist scholars from the $16^{\text {th }}-18$ th centuries, who had been animated by cultural interest and valued the best manuscripts available to them. Thus, the resources used by Micu were neither Orthodox nor Greek Catholic in origin.

Therefore, the Bible from 1914 is based on a remarkable biblical tradition, though mostly non-Orthodox. The value of the Bible from 1914 lies not in the fact that it was edited by Orthodox hierarchs and recommended by theologians of highest authority in the Romanian Orthodox Church of the $20^{\text {th }}$ century. But rather the value of the Bible from 1914 was increased by the alliance of multi-confessional and humanistic efforts that initially made

26 Robert H. Charles, The Apocrypha and Pseudoepigrapha of the Old Testamentin English, vol. 1, Oxford 1913, p. 616.

27 Present in the Bible from Ostrog (1581, in old Slavonic).

28 Biblia, adecă Dumnezeiasca Scriptură..., București, 1988 (reprint), p. 740-750: "A lui Iosip la Macavei carte, adecă pentru sîngurul-ţiitoriul gând".

29 Biblia de la Blaj, p. 883-893: "A lui Iosif Flavie". In the Preface, Micu said that the only reason for his reproducing of the apocryphal text was its existence in the Bucharest Bible.

30 The Prayer of Manasseh is printed in the Bibles of the Russian Orthodox Church after 2 Chronicles (БИБЛИЯ, ПЕТРОГРАДЬ, 1916, p. 537). However, the text is not printed in the editions of the Scriptures in the Greek Orthodox Church (thus Н АГІА ГРАФН,

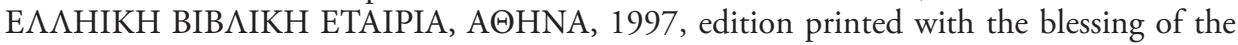
Greek Orthodox Church Holy Synod). 
possible the publication of the edition of the Blaj Bible and later favoured its adoption by the Romanian Orthodox Church.

\section{Conclusions}

Let us return to the questions in the introduction to this article. Is the autonomous development of Orthodox biblical theology possible? Could there be an Orthodox biblical science "untouched" by western biblical science?

Romanian Orthodox biblical theology went through the "Babylonian captivity" of western theology, especially in the $19^{\text {th }}$ and the $20^{\text {th }}$ century, when the systematization of theological education and the absence of literature in the field imposed the adoption of either Catholic or Protestant works as a model. The current trend is to find an appropriate profile of Orthodox biblical science, modelled on our own religious tradition. The focus is now on the liturgical and the ecclesial dimensions of biblical reading, on recovering the spirit of the Church Fathers' exegesis.

This process of finding our own identity is important for Orthodox biblical science and cannot be ignored. But the case of the Bible from 1914, discussed above, shows that an Orthodox work can be appreciated by Orthodox readership despite its reliance on non-Orthodox resources.

Therefore I believe that the mission of contemporary Orthodox biblical theology would be wrong if it pursued an autonomous profile, resistant to non-Orthodox influences. The search for the specific features of Orthodox biblical theology should develop taking into account heterodox biblical theology and making reference to its outcomes. 